\title{
PENERAPAN METODA TAGUCHI SEBAGAI USULAN PERBAIKAN KUALITAS DALAM MENGHADAPI PERMASALAHAN CACAT PADA PRODUK BOTOL MORNING FRESH (LIME) ISI 1000 ML DI CV. TUNGGAL JAYA PLASTICS
}

\author{
Hari Adianto ${ }^{1}$, Yeny Agustin ${ }^{2}$, Yogi Yusuf Wibisono ${ }^{3}$ \\ Jurusan Teknik dan Manajemen, Institut Teknologi Nasional ${ }^{1)}$ \\ Jurusan Teknik dan Manajemen, Universitas Katolik Parahyangan ${ }^{2,3)}$ \\ Bandung, Jawa Barat. \\ E-mail: hari@itenas.ac.id ${ }^{l}$
}

\begin{abstract}
One of the company efforts in increasing the sales volume of a product is with maintaining and increasing the quality of a product that have been produce by the company. Therefore, it is very important for the company to analyze and identify the problems that have been caused during the production process so the company can increase the quality of the product and productivity. Problems that cause during analyzing the defect product in production is how to arrange the optimal setting from each factor that significantly related so the company can minimize the defect product. This research was done at CV Tunggal Jaya Plastics and took the Morning Fresh (Lime) $1000 \mathrm{ml}$ case product. Taguchi method is one of the methods that can be used to minimize the defect product by applying robust system for uncontrollable factors. The final result is to know factors that related significantly to the defect product and suggest the level of each factor therefore the defect product can be minimized.
\end{abstract}

Keywords : Quality of The Product and Productivity, Taguchi Method.

\section{PENDAHULUAN}

Seiring dengan meningkatnya permintaan konsumen akan produk yang terbuat dari plastik mengakibatkan semakin ketatnya persaingan antar perusahaan plastik, dimana masing-masing perusahaan berusaha untuk menjaga kualitas plastik yang dihasilkannya untuk mempertahankan pangsa pasar yang ada sekaligus untuk meningkatkan volume penjualan. Produk yang terbuat dari plastik termasuk barang dengan konsumsi cukup tinggi, hal ini disebabkan karena plastik memiliki kelebihan-kelebihan seperti praktis dalam pemakaian, ringan, dapat dibuat berwarna atau transparan, bersifat isolator dan sebagainya.

CV. Tunggal Jaya Plastics merupakan salah satu perusahaan yang memproduksi produk yang terbuat dari plastik, salah satunya adalah produk botol Morning Fresh (1000 ml). Produk - produk dari bahan plastik lain yang dihasilkan oleh perusahaan selain tersebut diatas antara lain sendok susu, botol mineral water, cup, tutup cup dan lain sebagainya dengan sifat produksi sesuai pesanan dari perusahaan lain seperti PT. Nutricia Indonesia, PT. Helios Annot's Indonesia, PT. Tiga Raksa Satria, PT. Tang Mas, PT. Setiawijaya Bhaktisantosa dan sebagainya.

Botol Morning Fresh (Lime) isi $1000 \mathrm{ml}$ merupakan salah satu produk yang dihasilkan oleh perusahaan tersebut. Produk ini merupakan produk dengan cacat terbanyak di bandingkan dengan produk yang lainnya. Penyebab cacat tersebut dapat ditinjau dari beberapa faktor seperti: faktor material, mesin, metoda, lingkungan dan juga manusia.

Bagian pengendalian kualitas ini merupakan hal yang perlu diperhatikan secara serius mengingat menjaga kualitas berarti menjaga perusahaan tersebut untuk tetap dapat eksis dan bertahan di pasaran bahkan dapat mengembangkan pangsa pasarnya. Oleh karena itu, CV. Tunggal Jaya Plastics selalu berusaha untuk terus menerus berusaha secara berkesinambungan untuk meningkatkan sistem pengendalian kualitas 
sehingga diperoleh hasil produksi yang lebih optimal.

\subsection{Identifikasi masalah}

- Faktor - faktor apa saja yang berpengaruh pada cacat produk secara signifikan?

- Bagaimana membuat usulan pengendalian kualitas sehingga cacat produk dapat diminimasi ?

\subsection{Tujuan Penelitian}

- Menentukan faktor - faktor yang berpengaruh secara signifikan terhadap kualitas produk.

- Membuat usulan pengendalian kualitas dengan metoda Taguchi.

\subsection{Pembatasan Masalah dan Asumsi}

Pembatasan Masalah :

- Obyek penelitian adalah botol Morning Fresh Lime isi $1000 \mathrm{ml}$.

- Pengukuran dilakukan pada tekanan kompresor.

- Pengamatan pada faktor yang mempengaruhi cacat secara signfikan.

- Data didapat dari hasil pengamatan langsung, arsip dan wawancara langsung dengan pihak perusahaan hanya dilakukan pada satu mesin moulding machine saja.

Asumsi :

- Kinerja operator sesuai dengan prosedur standar.

- Mesin dalam keadaan baik, tidak ada penyesuaian dan perbaikan yang harus dilakukan terhadap mesin.

- Faktor - faktor seperti gempa bumi, kebakaran, dll tidak diperhitungkan.

Metodologi Penelitian,pada gambar 1.

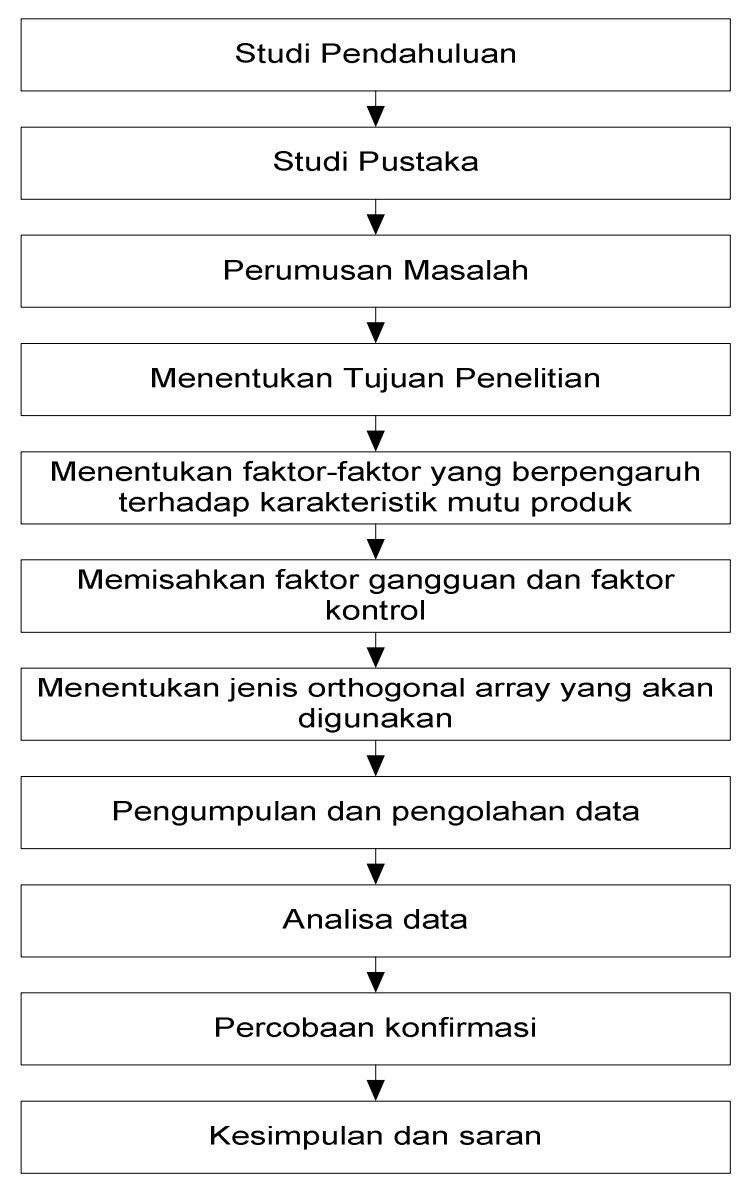

Gambar 1. Metodologi Penelitian.

\section{PENGUMPULAN DATA}

Pengumpulan data dari proses pembuatan botol Morning Fresh (Lime) isi $1000 \mathrm{ml}$ dilakukan dengan metode pengamatan dan wawancara langsung dengan pihak - pihak yang terkait pada CV Tunggal Jaya Plastics Tasikmalaya.

\subsection{Identifikasi Produk}

Produk yang dijadikan objek penelitian yaitu botol morning fresh (lime) isi $1000 \mathrm{ml}$. Jumlah produk botol morning fresh $1000 \mathrm{ml}$ yang dihasilkan oleh CV Tunggal Jaya Plastics Tasikmalaya dalam 1 shift adalah 2133 unit. Adapun berat dari botol tersebut adalah 69 - 71 gram. 


\subsection{Bahan-bahan Yang Digunakan}

\subsubsection{Bahan Baku}

Bahan baku yang digunakan dalam pembuatan botol Morning Fresh (lemon) isi $1000 \mathrm{ml}$ ini adalah PVC crystal 348 CRT. Bahan baku ini memiliki ciri :

- Biji plastiknya lunak / liat.

- Warnanya biru transparan.

- Bentuk bulat dengan diameter $5 \mathrm{~mm}$.

\subsubsection{Bahan Tambahan}

Selain bahan baku, juga diperlukan pewarna / pigmen yang ditambahkan pada proses pembuatan botol Morning Fresh (lemon) isi $1000 \mathrm{ml}$ adalah bahan pewarna Omni Green X-A 6175 yang berbentuk bubuk dan berwarna hijau.

\subsection{Proses Produksi Botol Morning Fresh (Lime) isi $1000 \mathrm{ml}$ di CV Tunggal Jaya Plastics}

\subsubsection{Proses Penggilingan}

Proses penggilingan yang berlangsung dengan menggunakan Mesin Crusher dimana mesin ini merupakan mesin otomatis sehingga operator hanya tinggal menekan tombol hijau untuk menyalakan mesin pada kontrol panel kemudian produk cacat (regrind) dan runner gate dari botol morning fresh $1000 \mathrm{ml}$ dimasukkan secara manual sedikit demi sedikit, hal ini dilakukan untuk mencegah cepat rusaknya pisau - pisau yang ada dalam mesin tersebut. Lamanya proses penggilingan (untuk $5 \mathrm{~kg}$ ) kira - kira 15 menit, kemudian hasil gilingan plastik keluar secara bertahap sampai 15 menit sehingga menghasilkan potongan - potongan kecil yang berukuran $4-5 \mathrm{~mm}$ yang siap dipakai.

\subsubsection{Proses Pencampuran}

Proses pencampuran ini dilakukan dengan Mesin Mixer dimana banyaknya bahan yang dimasukkan dalam tabung untuk sekali proses adalah $50 \mathrm{~kg}$. Mesin Mixer ini merupakan mesin otomatis sehingga operator tinggal menekan tombol hijau untuk memulai proses,. Bahan regrind dicampur dengan bahan origin dan pigmen (pewarna) lalu dimasukkan kedalam Mesin Mixer.
Proses pencampuran ini dilakukan dengan cara pengadukan secara merata di dalam sebuah mesin otomatis yang berbentuk tabung. Bahan yang telah sesuai dengan komposisi dimasukkan ke dalam tabung.

\subsubsection{Proses Blowing}

Sebelum proses blowing dimulai, dilakukan pemanasan terlebih dahulu. Bahan yang sudah mengalami proses pen campuran yang dikemas dalam karung dengan berat kurang lebih $25 \mathrm{~kg}$ dimasukkan dalam pengumpan (hopper). Dari pengumpan, bahan akan dilelehkan di dalam barrel dengan temperatur heater tertentu. Setelah itu, material akan diberi final temperatur tertentu sebelum lelehan material tersebut keluar dari parison. Siklus Produksi Botol Morning Fresh pada gambar 2.

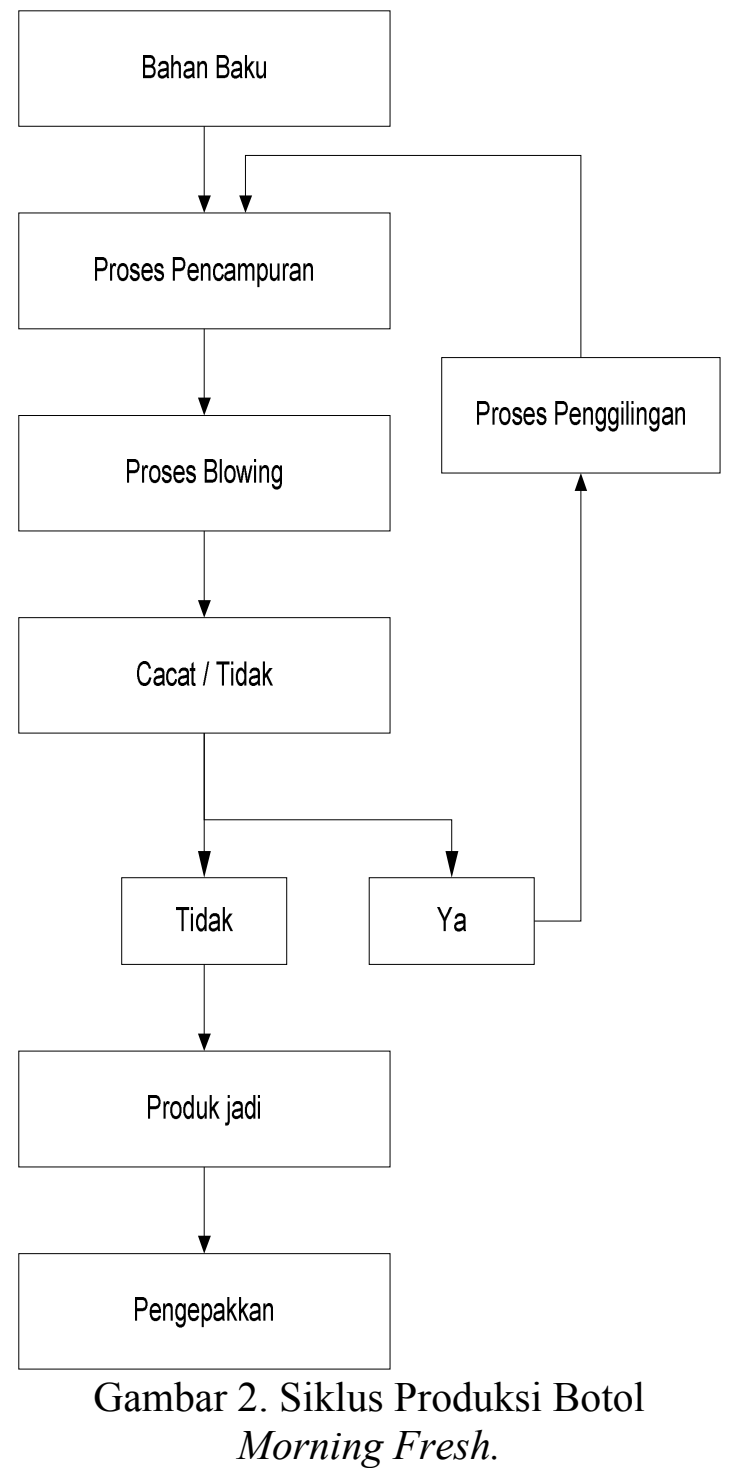




\subsection{Jenis Cacat yang Terjadi}

Berdasarkan wawancara dan hasil pengamatan di lapagan, terdapat beberapa jenis cacat yang dapat terjadi pada botol Morning Fresh 1000 ml. Cacat - cacat yang dapat terjadi diantaranya adalah :

a. Bintik Hitam

Merupakan cacat yang paling banyak terjadi di perusahaan tersebut. Bintik hitam dapat ditemukan pada permukaan botol yaitu berupa bintik kecil yang berwarna hitam. Maka operator harus membuang bintik hitam tersebut dengan gunting khusus sebelum produk dimasukkan ke mesin crusher untuk di daur ulang kembali. Adapun penyebab dari bintik hitam ini adalah adanya kotoran yang menempel pada bahan baku maupun pada bahan pewarna.

b. Tipis sebelah

Dikatakan tipis sebelah apabila tebal dinding botol tidak sama. Penyebab cacat ini adalah posisi blow pin tidak lurus saat meniupkan angin.

c. Kotor

Botol dikatakan cacat kotor apabila pada permukaan botol terdapat kotoran, debu atau oli. Hal ini dapat disebabkan karena adanya kotoran, debu atau oli yang menempel pada cetakan blowing sehingga botol harus didaur ulang kembali.

d. BS

Botol dikatakan BS jika, permukaan botol buram, tidak mengkilat atau tidak jernih, warna tidak seragam pada semua bagian. Hal ini disebabkan karena bahan baku berasal dari produk cacat terlalu sering didaur ulang, proses pencampuran bahan baku dan bahan tambahan yang tidak merata.

e. Flashing

Botol dikatakan flashing jika pada permukaan botol tersebut rebek sehingga masih ada sisa plastik yang harus dibuang. Hal ini dapat disebabkan karena proses blowing yang tidak tepat.

\section{f Bibir}

Botol dikatakan memiliki cacat bibir jika bibir botol bergelombang (tidak rata) dan tidak dapat match dengan cap nya. Hal ini dapat disebabkan umur cetakan yang sudah tua sehingga bibir botol dapat terdeformasi, Selain itu, cairan pendingin tidak berfungsi dengan baik pada proses blowing.

g Ekor

Botol dikatakan memiliki cacat ekor jika lelehan material yang dipotong oleh pisau pemotong terlalu pendek sehingga bagian bottom terlalu pendek sehingga bagian bottom berlubang. Hal ini biasanya dikarenakan pengaturan temperatur tidak tepat.

h Tidak Stabil

Botol dikatakan tidak stabil jika goyang atau tidak bisa berdiri di atas permukaan yang datar.

\section{PENGOLAHAN DATA}

Pengolahan data dimulai dengan menentukan faktor - faktor terkendali (control factors) dan faktor tidak terkendali (noise factor). Setelah itu dilakukan penentuan jenis orthogonal array berdasarkan jumlah faktor, jumlah level dan jumlah interaksi antara faktor. Data yang diukur adalah tekanan kompresor. Kemudian dilakukan pengolahan pada tertiary table, secondary table dan primary table. Hasil dari pengolahan dengan ANOVA tersebut adalah faktor - faktor yang berpengaruh terhadap nilai variansi dan nilai rata - rata. Strategi pooling up dilakukan untuk memaksimasi jumlah faktor yang signifikan. Kemudian hasil perhitungan tersebut, di plot ke dalam bentuk grafik sebagai usulan tingkat perlakuan yang akan diusulkan ke pihak perusahaan. Untuk memvalidasi usulan tersebut, dilakukan percobaan konfirmasi. Setelah itu, dilakukan perbandingan jumlah cacat sebelum dan sesudah metode Taguchi diterapkan. 
Tabel 1. Level untuk Faktor Terkendali

\begin{tabular}{l|c|c|c}
\hline \multicolumn{1}{c|}{ Faktor } & Level 1 & Level 2 & Level 3 \\
\hline Frekuensi kebersihan & Dibersikan setiap & Dibersihkan setiap 3 & Dibersihkan setiap \\
pengumpan (A) & jam & jam sekali & awal shift \\
Temperatur heater (B) & $145^{0} \mathrm{C}$ & $150^{0} \mathrm{C}$ & $155^{0} \mathrm{C}$ \\
Final temperatur (C) & $160^{0} \mathrm{C}$ & $170^{0} \mathrm{C}$ & $185^{0} \mathrm{C}$ \\
Bubble Delay (D) & 0.4 detik & 0.5 detik & 0.6 detik \\
Bubble On (E) & 8 detik & 8.5 detik & 9 detik \\
Temperatur cairan & $9^{0} \mathrm{C}$ & $8^{0} \mathrm{C}$ & \\
pendingin (F) & & & \\
\hline
\end{tabular}

Tabel 2. Level untuk Faktor Tidak Terkendali

\begin{tabular}{c|c|c|c}
\hline Faktor & Level 1 & Level 2 & Level 3 \\
\hline Tekanan kompresor & Shift 1 & Shift 2 & Shift 3 \\
\hline
\end{tabular}

3.1. Faktor - faktor yang Berpengaruh Terhadap Karaktreristik Mutu Produk

\section{a. Faktor Terkendali}

Faktor Kendali adalah faktor yang nilainya dapat diatur. Adapun faktor - faktor terkendali yang mempengaruhi karakteristik mutu produk adalah :

1. Frekuensi pembersihan pengumpan.

2. Temperature Heater adalah suhu pemanas pada ruang pemanas (barrel).

3. Final Temperature adalah suhu akhir material yang menunjukkan kapan proses pemanasan selesai.

4. Bubble Delay adalah lamanya waktu dari saat proses pemanasan selesai sampai proses peniupan material akan dimulai.

5. Bubble On adalah lamanya waktu peniupan material.

6. Temperatur cairan pendingin.

\section{b Faktor Tidak Terkendali}

Faktor tidak terkendali adalah faktor yang tidak dapat dikendalikan nilainya. Faktor tidak terkendali yang memberikan dampak yang signifikan pada cacat produk adalah tekanan kompresor. Hal ini disebabkan karena kompresor yang ada digunakan untuk menunjang seluruh kegiatan di pabrik tersebut. Tekanan kompresor tidak stabil karena tergantung pada jumlah mesin yang turut menggunakannya. Terdapat 27 mesin yang digunakan di CV. Tunggal Jaya Plastics. Diantaranya yaitu 22 mesin kategori injection moulding machine, 5 mesin kategori blow moulding machine. Mesinmesin tersebut digunakan sesuai dengan pesanan dari konsumen. Bila banyak mesin yang beroperasi, maka tekanan kompresor cenderung kecil karena kesemuanya menggunakan kompresor tersebut. Jika sedikit mesin yang beroperasi, maka tekanan kompresor cenderung lebih besar. Bila tidak ada pesanan dari konsumen, maka mesin berhenti bekerja untuk sementara waktu sampai perusahaan menerima pesanan selanjutnya.

\subsection{Penentuan Tingkat Perlakuan Faktor}

a Faktor-faktor terkendali pada tabel 1.

b Faktor tidak terkendali pada tabel 2.

\subsection{Pemilihan Orthogonal Array}

Dalam hasil penelitian ini, penulis menemukan bahwa dalam faktor terkendali terdapat 5 faktor dengan 3 level dan 1 faktor dengan 2 level dan terdapat 2 interaksi yaitu antara temperature heater dengan final temperature dan bubble delay dengan bubble on. Sedangkan untuk faktor tidak terkendali terdapat 1 faktor dengan 3 level. 
Tabel 3. Perhitungan ANOVA Untuk Nilai Rata - rata pooled.

\begin{tabular}{c|c|c|c|c|c|c}
\hline Sumber & SS & v & MS & F hitung & F tabel & Kesimpulan \\
\hline A & 0.323 & 2 & 0.161 & 2.388 & 3.039 & tidak signifikan \\
B & 1.000 & 2 & 0.500 & 7.388 & 3.039 & signifikan \\
C & 0.678 & 2 & 0.339 & 5.014 & 3.039 & signifikan \\
E & 0.786 & 2 & 0.393 & 5.808 & 3.039 & signifikan \\
SST1 & 2.5 & 8 & 0.312 & 4.616 & 1.979 & signifikan \\
DxW & 0.651 & 4 & 0.162 & 2.405 & 2.419 & tidak signifikan \\
FxW & 0.607 & 2 & 0.303 & 4.489 & 3.039 & signifikan \\
SST2 & 7.530 & 14 & 0.537 & 7.946 & 1.739 & signifikan \\
e & 13.605 & 201 & 0.067 & 1 & & \\
SST3 & 24.154 & 215 & 0.112 & 1.659 & & \\
\hline
\end{tabular}

Tabel 4. Tabel Perhitungan ANOVA Terhadap Nilai Variansi Unpooled

\begin{tabular}{c|c|c|c}
\hline Sumber & SS & $\mathbf{v}$ & MS \\
\hline A & 0.2635 & 2 & 0.13175 \\
B & 0.4116 & 2 & 0.2058 \\
C & 0.7026 & 2 & 0.3513 \\
D & 0.0134 & 2 & 0.0067 \\
E & 0.7297 & 2 & 0.36485 \\
F & 0.0591 & 1 & 0.0591 \\
BxC & 0.1854 & 4 & 0.04635 \\
DxE & 0.0735 & 4 & 0.018375 \\
\hline
\end{tabular}

Tabel 5. Penggolongan Faktor - faktor yang Berpengaruh Secara Signifikan terhadap Eksperimen

\begin{tabular}{c|c}
\hline $\begin{array}{c}\text { Faktor yang Mempengaruhi Nilai } \\
\text { Rata - Rata }\end{array}$ & Faktor yang Mempengaruhi Nilai \\
B & \\
C & - \\
E & \\
FW & \\
\hline
\end{tabular}

$\mathrm{DOF}=5(3-1)+1(2-1)+2(3-1)(3-1)+1=18$. Maka digunakan orthogonal array dengan tipe L18.

\subsection{Perhitungan Anova untuk Menen-} tukan Faktor yang Berpengaruh Secara Signifikan Terhadap Nilai Rata - rata dan Variansi

Data hasil dari hasil pelaksanaan eksperimen diolah dengan perhitungan ANOVA untuk menentukan faktor - faktor yang berpengaruh signifikan terhadap nilai rata - rata dan variansi. a. Tabel Perhitungan ANOVA untuk Nilai Rata - rata pooled.

Hasil perhitungan secara keseluruhan ANOVA Untuk Nilai Rata - rata pooled. dilihat pada tabel 3 .

\subsection{Perhitungan ANOVA untuk Menen- tukan Faktor yang Berpengaruh Secara Signifikan Terhadap Nilai Variansi}

ANOVA terhadap Nilai Variansi pooled, Pada tabel 4. dilakukan strategi pooling up terhadap faktor - faktor yang memiliki nilai rata - rata jumlah kuadrat lebih kecil dari 0.5 . 
Tabel 6. Tabel Perbandingan Persentase Cacat Sebelum dan Sesudah Metode Taguchi Diterapkan

\begin{tabular}{|c|c|c|c|c|}
\hline Jenis Cacat & Sebelum Taguchi & Sesudah Taguchi & $\begin{array}{c}\text { Penurunan } \\
\text { Jumlah Cacat }\end{array}$ & $\begin{array}{r}\text { Penurunan } \\
\text { Cacat }(\%)\end{array}$ \\
\hline Bintik hitam & 964 & 324 & 640 & 1.666 \\
\hline Tipis Sebelah & 33 & 36 & -3 & -0.007 \\
\hline Kotor & 136 & 72 & 64 & 0.166 \\
\hline $\mathrm{BS}$ & 99 & 72 & 27 & 0.070 \\
\hline Flashing & 45 & 36 & 9 & 0.023 \\
\hline Bibir & 54 & 36 & 18 & 0.046 \\
\hline Ekor & 39 & 36 & 3 & 0.007 \\
\hline Tidak Stabil & 38 & 36 & 2 & 0.005 \\
\hline Total cacat & 1408 & 648 & 760 & 0.019 \\
\hline $\begin{array}{c}\text { Total } \\
\text { produksi }\end{array}$ & 38394 & 38394 & Rata - rata & 0.247 \\
\hline
\end{tabular}

Dari hasil perhitungan ternyata semua faktor memiliki nilai rata - rata jumlah kuadrat lebih kecil dari 0.5 sehingga semua faktor mengalami pooling. Penggolongan Faktor - faktor yang Berpengaruh Secara Signifikan terhadap Eksperimen pada tabel 5.

Berdasarkan hasil perhitungan yang telah dibuat maka penulis mengusulkan tingkat perlakuan dari setiap faktor utama adalah :

- Faktor A (frekuensi kebersihan pengumpan) : dibersihkan setiap jam.

- Faktor B (Temperatur Heater) : $150^{\circ} \mathrm{C}$.

- Faktor C (Final Temperatur) $: 170^{\circ} \mathrm{C}$.

- Faktor D (Bubble Delay) : 0.5 detik.

- Faktor E (Bubble On) : 8.5 detik.

- Faktor F (Temperatur Cairan Pendingin) : $9^{0} \mathrm{C}$.

Tabel perbandingan prosentase cacat sebelum dan sesudah penerapan metoda Taguchi, pada tabel 6 .

\section{ANALISIS}

\subsection{Analisis Faktor Terkendali}

1. Faktor kebersihan pengumpan

Faktor terkendali yang mempunyai pengaruh secara signifikan adalah kebersihan pengumpan. Bila pengumpan kotor karena debu, kotoran atau pun oli, maka kotoran tersebut akan terbawa bersamaan dengan material pada saat material dialirkan ke ruang pemanas dan parison sehingga pada saat proses peniupan material selesai produk menjadi cacat. Beberapa jenis cacat yang dapat terjadi adalah bintik hitam, kotor karena debu atau pun oli. Biasanya, pihak perusahaan membersihkan pengumpan setiap awal shift.

2. Faktor Temperatur Heater

Faktor terkendali lain mempunyai dampak yang signifikan pada cacat produk yaitu faktor temperatur heater. Faktor ini dapat diatur secara otomatis pada panel mesin. Setiap produk kemasan plastik yang dibuat mempunyai setting temperatur heater yang berbeda. Hal ini bergantung pada titik leleh materialnya. Heater berfungsi untuk melelehkan material yang dimasukkan dari pengumpan. Untuk produk botol morning fresh $1000 \mathrm{ml}$ dengan jenis material PVC ini mempunyai temperatur feasible antara $145^{\circ}$ $155^{\circ} \mathrm{C}$. Jika material diberi temperatur heater jauh melebihi $155^{\circ} \mathrm{C}$, maka material akan hangus pada barrel atau pun parison. Untuk material HD PE mempunyai setting temperatur heater yang lebih tinggi dibandingkan dengan material PVC.

3. Faktor Final Temperature

Faktor final temperature juga mempengaruhi cacat produk botol Morning Fresh. Suhu akhir material yang 
menunjukkan kapan proses pemanasan ini selesai (final temperature) juga dapat diatur secara otomatis pada panel. Final temperatur ini berpengaruh pada lelehan material yang keluar dari parison. Untuk produk botol Morning Fresh ini, pengaturan final temperatur feasible berada diantara $160^{\circ}$ $185^{\circ}$ C. Jika final temperatur diset melebihi $185^{\circ} \mathrm{C}$ mula - mula lelehan material ini akan mempunyai warna yang berbeda dengan warna standar yang diinginkan.

\section{Faktor Bubble Delay}

Faktor bubble delay mempunyai pengaruh signifikan terhadap cacat produk. Bila bubble delay diset terlalu lama, maka blow pin sudah masuk ke dalam cetakan tetapi belum meniupkan angin sehingga bentuk produk tidak dapat mengembang, tidak lengkap atau pun keriput. Maka, bubble delay diatur tidak lama setelah material dijepit oleh cetakan (pada saat pin mulai turun dan akan memasuki cetakan), pin mulai meniupkan angin agar stricle plate dapat terbuka saat pin mulai memasuki cetakan untuk meniupkan angin. Oleh karena itu, bubble delay diset antara 0,4-0,6 detik.

\section{Faktor Bubble On}

Faktor lama peniupan material ini juga sangat berdampak pada cacat produk botol tersebut. Bubble On diset pada batas feasible-nya yaitu antara $8-9$ detik. Jika bubble on diset kurang dari 8 detik maka material belum mengembang dengan lengkap untuk memenuhi cetakan tersebut. Batas feasible bubble on ini adalah 9 detik. Lamanya proses peniupan material disesuaikan dengan bentuk produk yang diinginkan. Jika produk yang diinginkan tergolong dalam ukuran yang besar maka proses peniupan akan lebih lama dibandingkan dengan produk yang kecil.

\section{Faktor Temperatur Cairan Pendingin}

Cairan pendingin yang mengalir pada proses peniupan material dapat diatur temperaturnya. Pengaturan ini dilakukan pada mesin Jet Pump Chiller. Mesin Jet Pump Chiller ini berfungsi sebagai mesin pembangkit tenaga air yang disalurkan melalui selang air. Jadi, mesin ini berfungsi untuk proses pendinginan pada bagian cetakan pada proses pengepresan berlangsung dengan mengalirkan air yang telah di dinginkan. Temperatur cairan pendingin dapat diset pada $8^{0}$ dan $9^{\circ} \mathrm{C}$. Bila produk yang dihasilkan belum sempurna, maka temperatur cairan pendingin diturunkan suhunya. Pada proses peniupan material, cairan pendingin ini mengalirkan air ke dekat bagian neck, body dan bottom. Hal ini dilakukan untuk mendinginkan produk sebelum produk keluar dari cetakan. Jika temperatur cairan pendingin kurang dingin, maka material akan menempel (lengket) pada cetakan karena material masih panas pada saat keluar dari cetakan tersebut. Selain itu, cairan pendingin dialirkan pada blow pin untuk mendinginkan pin yang telah digunakan pada proses peniupan. Bila bak penampung cairan pendingin kurang terjaga kebersihannya, maka akan ada bekas kotoran, debu atau oli yang mengalir pada cairan pendingin yang akan menyumbat cetakan tersebut sehingga pendinginan tidak bekerja dengan sempurna dan produk lengket dengan cetakan ataupun produk keriput, tidak mengembang dengan sempurna.

\subsection{Analisis Hasil Perhitungan ANOVA untuk Menentukan Faktor - faktor yang Berpengaruh Secara Signifikan Terhadap Nilai Rata - rata}

Hasil perhitungan ANOVA untuk menentukan faktor - faktor yang berpengaruh secara signifikan terhadap nilai rata - rata dapat dilihat pada tabel 3. Tabel tersebut merupakan tabel hasil perhitungan ANOVA yang unpooled. Setelah dilakukan perhitungan, didapatkan nilai rata - rata jumlah kuadrat eror $\left(\mathrm{MS}_{\mathrm{e}}\right)=0.10136$. Bila nilai rata - rata jumlah kuadrat faktor lebih kecil daripada nilai rata - rata jumlah kuadrat error, maka dilakukan pengabaian karena faktor tersebut memiliki kontribusi yang sangat kecil terhadap nilai rata - rata. Faktor - faktor yang mengalami pengabaian adalah faktor $\mathrm{D}$, faktor $\mathrm{F}$, interaksi faktor $\mathrm{BC}$, 
interaksi faktor DE, interaksi faktor AW, interaksi faktor $\mathrm{BW}$, interaksi faktor $\mathrm{CW}$, interaksi antara faktor $\mathrm{EW}$, interaksi antara faktor $\mathrm{BC}$ dan $\mathrm{W}$, interaksi antara faktor $\mathrm{DE}$ dan $\mathrm{W}$.

\subsection{Analisis Hasil Perhitungan ANOVA untuk Menentukan Faktor yang Berpengaruh Secara Signifikan Terhadap Nilai Variansi}

Rasio Signal-to-Noise yang digunakan adalah Lower is better characteristic. Tujuan dari perancangan parameter ini adalah mendapatkan hasil yang baik dengan cacat yang seminimal mungkin. Hasil perhitungan ANOVA untuk menentukan faktor yang berpengaruh terhadap nilai variansi secara signifikan dapat dilihat pada tabel 4. Dari hasil perhitungan tersebut, dilakukan strategi pooling up terhadap faktor - faktor yang memiliki nilai rata - rata jumlah kuadrat yang lebih kecil dari 0.5. Dari kesemua faktor $\mathrm{A}, \mathrm{B}, \mathrm{C}, \mathrm{D}, \mathrm{E}, \mathrm{F}, \mathrm{BxC}, \mathrm{DxE}$, tidak terdapat faktor yang berpengaruh terhadap nilai variansi secara signifikan.

\section{KESIMPULAN DAN SARAN}

\subsection{Kesimpulan}

1. Faktor - faktor yang memberikan pengaruh secara signifikan terhadap cacat botol Morning Fresh adalah :
a. Temperature Heater.
b. Final Temperature.
c. Bubble On.

Kualitas produk bergantung pada pengaturan temperature heater.

2. Usulan tingkat perlakuan untuk masing masing faktor digunakan adalah sebagai berikut : Kebersihan pengumpan dibersihkan setiap jam :
a. Temperature Heater
b.Final Temperature
$: 150^{\circ} \mathrm{C}$.
c. Bubble Delay $\quad: 0.5$ detik.
d. Bubble On $\quad: 8.5$ detik.
e. Temperatur Cairan Pendingin : $9^{0} \mathrm{C}$.
f. Rata - rata penurunan cacat setelah metode Taguchi diterapkan $=0.33 \%$.

\subsection{Saran}

a. Melakukan pengendalian kualitas secara online seperti metode EVOP (Evolutionary Operation).

b. Menerapkan metoda Taguchi terhadap produk yang lain seperti botol air mineral, sendok susu, dan lain - lain sehingga dapat diketahui setting optimal untuk tiap - tiap produk.

\section{DAFTAR PUSTAKA}

Bagchi, Tapan P. Taguchi Methods Explained, Control and Improvement. New Jersey : dan Ongkos Produksi dengan Memper Engineering : lost function, orthogonal experiments, parameter and tolerance design.

Feigenbaum, A.V. 1991. Total Quality Control. New : McGraw-Hill.

Irianto, D. Pengaruh Toleransi Terhadap Harga dan Ongkos Produksi dengan Memper timbangkan Fungsi Kerugian Kuadratik. Jurnal TMI no. 18.

Mitra, Amitava. 1993. Fundamentals of Quality Control and Improvement. New Jersey : Prentice-Hall.

Peace, Glen Stuart, 1993. Taguchi Methods, A Hands - On Approach. Massachusetts : Addison Wesley.

Ross, Phillip J, 1995. Taguchi Techniques for Quality Engineering : lost function, orthogonal experiments, parameter and tolerance design. New York : McGraw-Hill. 